\title{
Changes in biodiversity and environmental stressors influence community structure of an experimental eelgrass Zostera marina system
}

\author{
Rachael E. Blake*, J. Emmett Duffy \\ Virginia Institute of Marine Science, College of William \& Mary, Gloucester Point, Virginia 23062, USA
}

\begin{abstract}
Changes in biodiversity can result in decreased ecosystem functioning and loss of ecosystem services, but altered biodiversity is only one of many stressors impacting ecosystems. In many estuaries, environmental stressors such as warming water temperatures and eutrophication are increasing and negatively impacting biological communities, particularly seagrasses such as the important habitat-forming species Zostera marina (eelgrass). These negative impacts may change the diversity, composition, and functioning of this important ecosystem, but the interactions of stressors with changes in biodiversity are poorly understood. We manipulated eelgrass communities in a factorial experiment to test how changes in crustacean grazer diversity, warmer water temperatures, and nutrient enrichment interact to affect ecosystem biomass, stability, and community composition. We found that the presence and richness of crustacean grazers had a larger effect on grazer, algal, and sessile invertebrate biomass than experimental warming or nutrient enrichment. Diverse grazer assemblages stabilized epiphytic algal biomass in the face of stressors, and counteracted the promotion of epiphytic microalgae by stressors. Nutrient enrichment and warming both promoted epiphytic microalgae, while reducing macroalgae and eelgrass. A more diverse grazer assemblage stabilized epiphytic algal biomass, but we did not detect interactions among environmental stressors and grazer diversity. These results emphasize that loss of herbivore diversity can exacerbate the impacts of environmental stressors on grazing, relative dominance of microalgae versus macrophytes, producer biomass, and stability.
\end{abstract}

KEY WORDS: Diversity $\cdot$ Stressors $\cdot$ Eelgrass $\cdot$ Grazers

Resale or republication not permitted without written consent of the publisher

\section{INTRODUCTION}

There is increasing evidence that biodiversity, the variety of life, supports ecosystem processes, properties, and functions that are ecologically and economically important, such as water and nutrient cycling and fisheries production (Cardinale et al. 2012). Higher diversity among and within trophic levels can positively affect resource use and production, and increase stability (Tilman 1996, Tilman et al. 1998, Griffiths et al. 2000, Duffy et al. 2003, Allison 2004, Caldeira et al. 2005, Balvanera et al. 2006, Blake \& Duffy 2010). Increased biomass within a functionally diverse assemblage has the potential to enhance important ecosystem processes, such as grazing, that play critical roles in marine systems (Worm et al. 1999, Nyström et al. 2000, Duffy et al. 2003, Valentine \& Duffy 2006, Stachowicz et al. 2007). However, biodiversity on both global and local scales is threatened, largely by human activities that are rapidly changing ecosystems. These changes in biodiversity are of concern because they can result in losses of important ecosystem functions (Tilman 1999). Change in biodiversity also acts as a stressor in ecological systems, and may interact with and be as important as, or more important than, other stressors 
in marine systems (Stachowicz et al. 2007, Hooper et al. 2012). The impacts of biodiversity change and other stressors in marine systems are an increasing concern because we know little about their interactions, especially in the context of global climate change.

Climate change is a primary threat affecting marine systems around the globe, and the impacts are predicted to increase as more $\mathrm{CO}_{2}$ is dissolved in the oceans, global temperatures continue to warm, and ocean circulation patterns change (Doney et al. 2012). Climate warming, an important stressor, is predicted to increase both extreme temperatures as well as mean temperatures (Najjar et al. 2010, Doney et al. 2012). Warming temperatures can lead to changes in oceanic physical processes and chemical properties such as ocean circulation, sea level, and dissolved oxygen concentrations that can impact other components of marine communities. Increased water temperatures can alter ecosystem properties, services, and functions indirectly through effects on the diversity of organisms in a community, or directly through effects on biomass and primary production. Water temperatures in most shallow temperate estuaries along the US east coast closely follow changes in air temperatures (Najjar et al. 2000). In one such estuary, Chesapeake Bay, average temperatures are predicted to increase by 2 to $6^{\circ} \mathrm{C}$ by the end of the 21st century (Najjar et al. 2010). Warmer waters may influence biogeochemical cycling, life histories and ranges of resident and transient organisms, fisheries production, and important habitats such as salt marshes, oyster reefs, and seagrass beds (Short \& Neckles 1999, Hoegh-Guldberg \& Bruno 2010, Doney et al. 2012).

Increasing pressure is also being put on coastal habitats as human populations in the coastal zone continue to rise (McGranahan et al. 2007). Anthropogenic impacts along coasts include shoreline hardening and development in coastal zones for residential, commercial, and recreational use. This development leads to decreased filtration of runoff through loss of vegetation buffers, and increased direct inputs of sewage, fertilizer, and pollutant runoff to coastal waters (Vitousek et al. 1997, Kemp et al. 2005). These impacts have led to the eutrophication of estuaries, such as Chesapeake Bay, which are now characterized by increased occurrence of bloom forming micro- and macroalgae (Hauxwell et al. 2001, Burkholder et al. 2007, Najjar et al. 2010). The conditions that favor blooms of ephemeral algae are, at the same time, detrimental to important habitats such as seagrass meadows.
Seagrass systems are important habitats in Chesapeake Bay that provide shelter for juvenile fish and crabs, stabilize sediments and coastlines, and sequester carbon (Duarte 2000, Heck et al. 2003, Duarte et al. 2005, Polte et al. 2005, Canuel et al. 2007). Historically the dominant seagrass in Chesapeake Bay, eelgrass Zostera marina is declining at an accelerated pace due largely to recent record summer temperatures and continued eutrophication (Orth \& Moore 1983, 1988, Orth et al. 2002, 2006, Moore \& Jarvis 2008). Elevated temperatures, especially in the summer months, can lead to eelgrass dieoffs (Bintz et al. 2003, Oviatt 2004). These declines are attributed to higher respiration than production, internal carbon stress, and reduced growth rates in eelgrass (hereafter referred to as Zostera) under higher temperature conditions (Short \& Neckles 1999, Touchette \& Burkholder 2000, Bintz et al. 2003, Touchette et al. 2003).

Eutrophication has negative consequences for Zostera, both direct and indirect. Nutrient enrichment impacts eelgrass physiology similarly through carbon limitation and ammonium toxicity, both of which lead to reduced shoot production and overall growth (Touchette \& Burkholder 2000, Touchette et al. 2003). Indirect impacts of nutrients on Zostera include overgrowth by micro- and macroalgae, and associated light limitation (Hauxwell et al. 2001, Burkholder et al. 2007). However, extensive previous work shows that grazing by invertebrates such as amphipods and isopods in temperate seagrass beds can counteract algal overgrowth, thus fostering dominance by seagrasses, and that grazing has effects of similar or greater magnitude to water column nutrient enrichment (Neckles et al. 1993, Hughes et al. 2004). While grazing has the potential to counter the effects of water column nutrient enrichment in some circumstances (Neckles et al. 1993, Hays 2005, Jaschinski \& Sommer 2011), Zostera habitats in Chesapeake Bay are increasingly faced with multiple simultaneous stressors whose interactions are poorly understood and difficult to predict (Orth et al. 2006).

In the present study, we examined the effects of crustacean grazer diversity, warming, and nutrient enrichment on the ecosystem properties of experimental seagrass communities. We wanted to investigate indirect impacts of stressors on ecosystem function through changes in grazer diversity, as well as direct impacts of stressors on ecosystem function. We planted outdoor mesocosms with Zostera marina, stocked the crustacean grazers species Elasmopus levis, Erichsonella attenuata, and Gammarus mucro- 
natus alone and in mixture, and assessed their impacts on abundance and biomass of primary producers, grazers, and fouling invertebrates. Specifically, we tested whether (1) grazing effects were of similar magnitude as stressor effects, (2) stressors affected primary producer community composition and relative dominance, and (3) change in biodiversity interacted with stressors to exacerbate or buffer against stressor impacts. We show that stressors facilitate microalgae at the expense of macrophytes, that grazing effects are large and counteract these stressor effects, but that there were no non-additive interactions between loss of species richness and stressor impacts.

\section{MATERIALS AND METHODS}

\section{Experimental design}

We manipulated crustacean grazer species richness, water temperature, and water column nutrients in a factorial mesocosm experiment during the summer of 2007. Located outdoors at the Virginia Institute of Marine Science, Gloucester Point, Virginia, USA $\left(37.25^{\circ} \mathrm{N}, 76.50^{\circ} \mathrm{W}\right)$ in a flow-through tank system, experimental mesocosms (one hundred $19 \mathrm{l}$ buckets consisting of 5 replicates of 20 unique treatments) were supplied with filtered estuarine water from the adjacent York River. In order to exclude crustacean grazer recruits but allow algal and sessile invertebrate propagules to recruit to the mesocosms, estuarine water was filtered by a coarse sand filter and then through $150 \mu \mathrm{m}$ mesh. Mesocosms were surrounded by a $25 \mathrm{~cm}$ deep water bath to buffer diurnal temperature changes, and were covered by shade screens to reduce downwelling insolation by about $60 \%$ and to approximate light conditions found in local seagrass beds. Each mesocosm contained a substrate mixture of approximately $2.5 \mathrm{l}$ of sand and $0.5 \mathrm{l}$ of mud, and was planted with 30 shoots of defaunated Zostera marina to approximate field shoot densities.

We used 2 amphipod species (Gammarus mucronatus and Elasmopus levis) and 1 isopod species (Erichsonella attenuata) to establish 5 grazer treatments: each species as a monoculture (1 species), a multispecies assemblage ( 3 species), and a grazer-free control. These grazer species (hereafter referenced by genus) are among the 5 most abundant crustacean grazers present in local eelgrass beds in the summer season, and consume a variety of epiphytic macroand microalgae (Cruz-Rivera \& Hay 2000, Duffy \&
Hay 2000, Duffy \& Harvilicz 2001, Douglass et al. 2010). Grazers were added to mesocosms in a replacement design, with monocultures receiving 30 individuals of 1 species and multi-species assemblages receiving 10 individuals of each species. Mesocosms were either left at ambient water temperature, or were heated approximately $3^{\circ} \mathrm{C}$ above ambient water temperature using a $200 \mathrm{~W}$ aquarium heater (warmed treatment). This warming simulated a realistic climate warming scenario projected for Chesapeake Bay (Najjar et al. 2010). Slow-release pelletized fertilizer $\left(\right.$ Osmocote ${ }^{\circledR}, \quad \mathrm{N}: \mathrm{P}: \mathrm{K}=3: 1: 2$ ) was used to enrich nutrient levels to approximately 5 times ambient levels in the nutrient-addition treatments. The fertilizer (15 to $20 \mathrm{~g}$ ) was contained in fine mesh inside a perforated PVC tube and suspended in the nutrient-enriched mesocosms. Fertilizer was replaced every 4 days to maintain elevated nutrient levels (Spivak et al. 2009). Water column nutrients in each mesocosm were tested for the amount of ammonium once during the experiment to assess the enrichment treatment. Both the temperature and nutrient treatments were applied continuously, and grazers had sufficient time to reach carrying capacity, approximately 2 overlapping generations (Sainte-Marie 1991), during the 6 wk duration of the experiment.

During the experiment, epiphytic chlorophyll a was sampled from standardized artificial seagrass units (ASUs) placed in each mesocosm at the start of the experiment (4 ASUs of 2 polypropylene ribbons each), as a proxy for epiphytic algal biomass (Parsons et al. 1984). One ASU was removed during Weeks 2 , 4, and 6, and processed using standard procedures (Parsons et al. 1984). Grazer density was estimated non-destructively at those same time points by catching grazers in 3 standardized dip-net sweeps. All captured grazers were counted, identified, and returned to their respective original mesocosms.

At the conclusion of the experiment, all biomass was harvested from each mesocosm and frozen until samples could be processed. Thawed biomass retained on a $500 \mu \mathrm{m}$ sieve was sorted to the lowest taxonomic level possible, dried in a $60^{\circ} \mathrm{C}$ oven until the mass was stable, and then combusted at $450^{\circ} \mathrm{C}$ to obtain ash-free dry mass (AFDM). Grazers were sorted by size (using sieves with mesh sizes of 8.0, $5.6,4.0,2.8,2.0,1.4,1.0,0.71$, and $0.05 \mathrm{~mm}$ ), identified to species, and enumerated. Biomass of grazers was calculated using the empirical equation, $\log B=$ $-1.01+2.64 \times \log S$, where $B$ is AFDM $(\mathrm{mg})$, and $S$ is the sieve size $(\mathrm{mm})$ on which the animal was retained (Edgar 1990). 


\section{Statistical analysis}

We used 3-way factorial ANOVAs to test for main and interactive effects of warming, nutrients, and crustacean grazer species richness on Zostera shoot biomass, epiphytic algal biomass, macroalgal biomass, and sessile invertebrate biomass (SAS Enterprise Guide 4.3). All data were untransformed with the exception of the epiphytic chlorophyll a data, which were $\log$ transformed to improve normality. We also used a priori orthogonal contrasts to test for the effects of grazer presence (all treatments with grazers vs. no-grazer controls) and grazer species richness (grazer monocultures vs. 3-species assemblage treatments). To estimate the size of effects in the ANOVA analyses, we calculated the $\omega^{2}$ values for each main effect and interaction using the generalized equation of Olejnik \& Algina (2003):

$$
\begin{gathered}
\omega^{2}=\left[\mathrm{SS}_{\text {effect }}-\mathrm{df}_{\text {effect }} \times \mathrm{MS}_{\text {error }}\right] / \\
{\left[\mathrm{SS}_{\text {effect }}+\left(\mathrm{N}-\mathrm{df}_{\text {effect }}\right) \times \mathrm{MS}_{\text {error }}\right]}
\end{gathered}
$$

To examine whether crustacean grazer species richness had a stabilizing effect on ecosystem properties in the face of environmental stressors, we used the Brown-Forsythe test (Brown \& Forsythe 1974, Blake \& Duffy 2010). This variation of Levene's test (Levene 1960) employs the median rather than the mean in testing for equality of variance. We tested both community resistance to stressors (variation among stressor treatments), as well as stochastic variation within communities (variation among replicates within stressor treatments) (see Blake \& Duffy 2010 for further details and equations).

We also used multivariate non-metric multidimensional scaling (NMDS) to examine which factors most influenced the similarity and composition of communities among all mesocosms in the experiment. We conducted the analysis in R 2.13.0 (R Development Core Team 2011), using the metaMDS function in the vegan package (Oksanen et al. 2011) and a BrayCurtis dissimilarity matrix. Instead of using untransformed data as suggested by the default settings in metaMDS, we square-root transformed the data to reduce the influence of very abundant species. We plotted the results in 2 dimensions, and used the envfit procedure in vegan (Oksanen et al. 2011) to overlay species vectors (determined by principal components analysis) on the final NMDS plot. To statistically test the results of the NMDS ordination, we conducted PERMANOVA using the adonis function in the vegan package. This routine carries out an analysis of variances test using a dissimilarity matrix, and a permutation test to determine significance. It is an especially appropriate test for ecological data because it uses a non-Euclidian distance matrix, is robust to multivariate non-normality, and handles datasets with more variables than degrees of freedom (McArdle \& Anderson 2001). We also examined the multivariate homogeneity of the treatments using the function betadisper in the vegan package, which is analogous to Levene's test for equality of variances (Levene 1960).

To examine the direct and indirect effects of warming, nutrients, and crustacean grazer species richness on primary producer biomass and sessile invertebrate biomass, we used maximum-likelihood estimated structural equation models created with Amos 18.0.0 (Arbuckle 2011). Structural equation modeling (SEM) is a multivariate framework for graphical modeling and analysis that draws from both path and factor analysis techniques (Grace 2006). SEM allows for the exploration of direct and indirect causal relationships between observed and hypothesized (latent and composite) variables through paths relations, and is well suited to studying systems with multiple simultaneous processes (Grace et al. 2010).

Models were evaluated based on criteria described in Grace (2006). It is important to note that we used SEM in the 'model generating' mode. We first specified an initial model based on theory and previous knowledge of our experimental system, after which we modified and re-tested this model until the model fit the data well from both statistical and ecological points of view.

Grazer treatments in 4 mesocosms were contaminated, and thus removed from all statistical analysis. All treatments retained a minimum of 4 replicates.

\section{Background environmental conditions}

Global surface temperatures in the summer of 2007 were the seventh warmest on record. In the continental USA, 2007 was the sixth warmest summer since records began in 1895, and the average temperature was $1{ }^{\circ} \mathrm{C}$ above the 20th century mean (NOAA 2007). In the York River, Virginia, water temperatures averaged $26^{\circ} \mathrm{C}$, and the average daily maximum temperature was $27^{\circ} \mathrm{C}$ in the period from June through July (VECOS 2012). Experimental mesocosms at ambient temperature had an average daily maximum of $29^{\circ} \mathrm{C}$, while warmed mesocosms averaged $31^{\circ} \mathrm{C}$ (Fig. 1).

Precipitation in the summer of 2007 was below average both nation-wide and in Virginia. Much of the Chesapeake Bay watershed experienced abnor- 

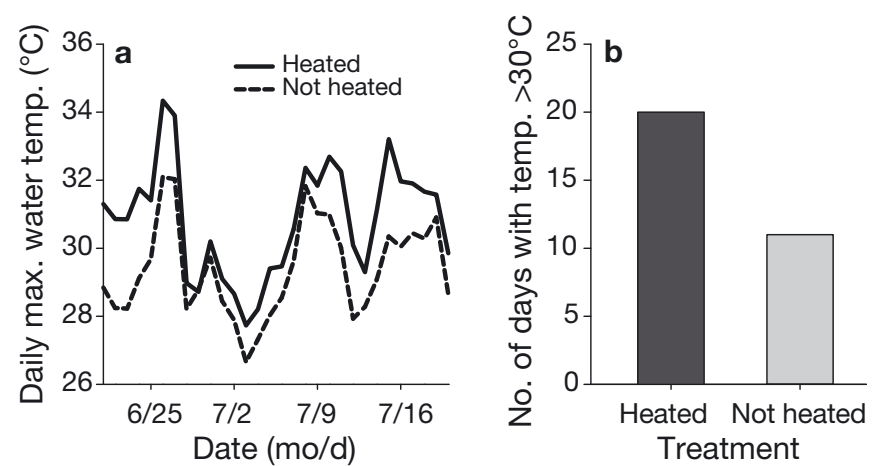

Fig. 1. (a) Average maximum daily water temperatures in heated (solid line) and unheated (dashed line) treatments over the duration of the experiment. (b) Number of days during the experiment with maximum water temperatures over $30^{\circ} \mathrm{C}$ in heated and unheated treatments

mally dry to moderate drought conditions during these months (NOAA 2007). Salinity averaged $20 \mathrm{ppt}$ both in the York River and in the mesocosms during this experiment.

Ambient nutrient levels in the York River, measured as concentration of $\mathrm{NH}_{4}{ }^{+}$, averaged $2 \mu \mathrm{M}$ during this experiment. In nutrient enriched treatments, $\mathrm{NH}_{4}{ }^{+}$averaged $10 \mu \mathrm{M}$, or 5 times ambient nutrient levels. This level of nutrient enrichment is at or above the levels found at sites that no longer support Zostera, and is comparable to the levels used in previous studies simulating eutrophication in this system (Moore \& Wetzel 2000, Spivak et al. 2009).

\section{RESULTS}

\section{Species richness and multiple stressors}

Crustacean grazer treatments, including grazer presence, had the largest effect of any experimental treatment in this study (Table 1). Crustacean grazer presence significantly reduced the biomass of epiphytic microalgae, macroalgae (Ceramium spp., Polysiphonia spp., Enteromorpha spp., and Cladophora spp.), and sessile invertebrates (Molgula manhattensis, Botryllus schlosseri, and Balanus improvisus) in experimental communities ( $\mathrm{p}<0.0001, \mathrm{p}=$ 0.0052 , and $p=0.0002$ respectively; Fig. 2, Table 1). Species-rich grazer treatments also reduced macroalgal biomass more strongly than the average single species treatment $(p=0.0255$; Fig. $2 \mathrm{c}$, Table 1$)$. Although all grazer treatments began with the same abundance, final biomass of crustacean grazers was significantly greater in species-rich grazer treatments compared to the average single-species grazer

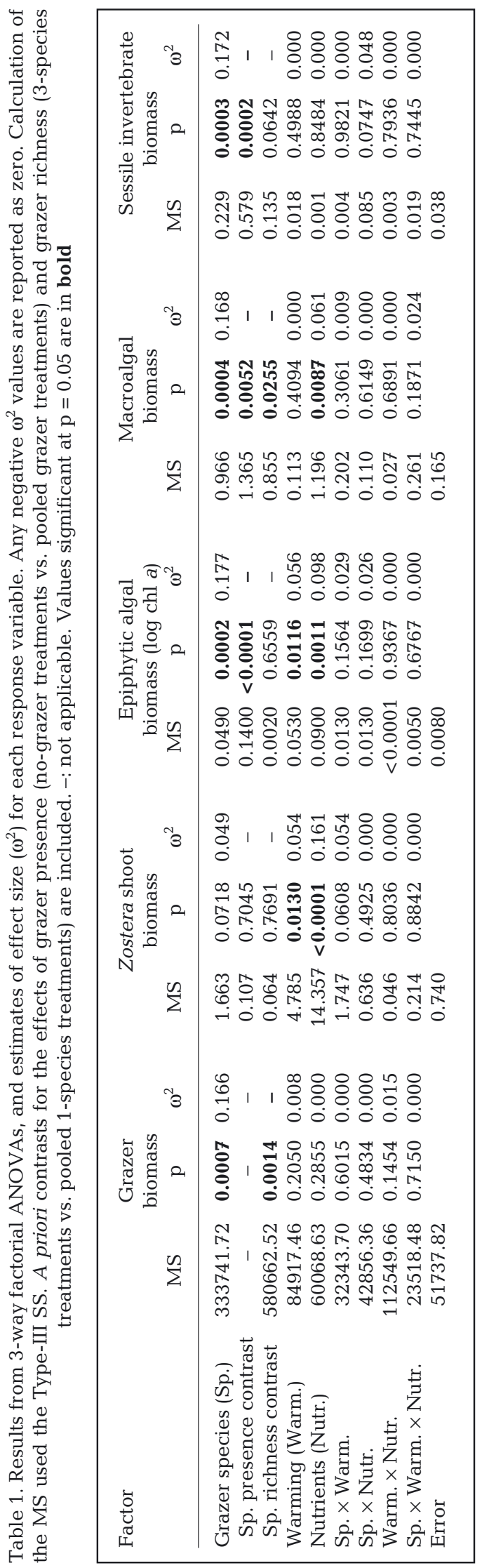



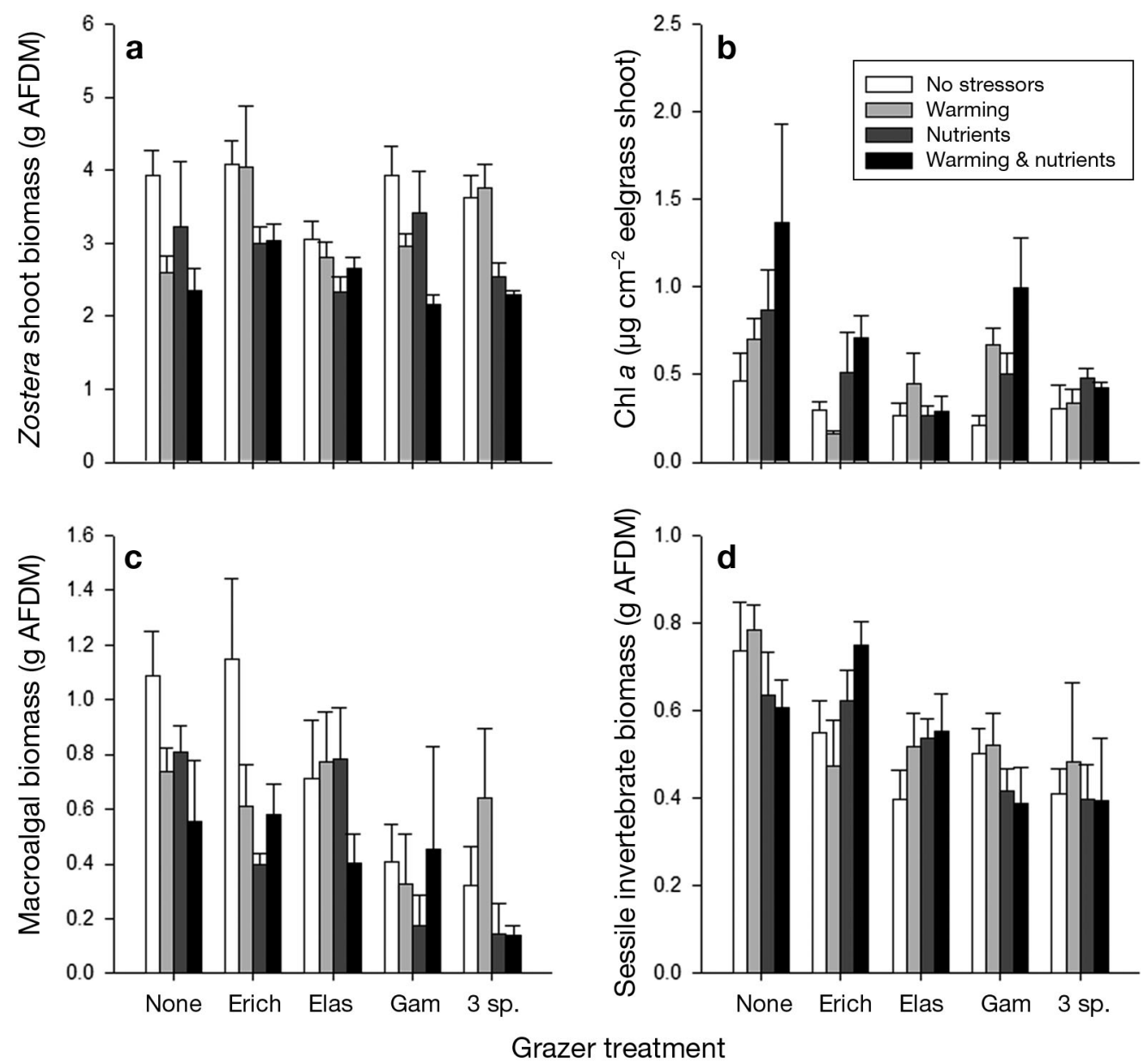

Fig. 2. Final biomass ( $\pm 1 \mathrm{SE}$ ) of (a) Zostera shoots (aboveground biomass), (b) epiphytic algae (as chlorophyll a), (c) macroalgae (primarily Cladophora sp., Ulva sp., Ceramium sp., Polysiphonia sp.), (d) sessile invertebrates (Botryllus schlosseri, Molgula manhattensis, and Balanus improvisus). None: no grazers; Erich: Erichsonella attenuata alone; Elas: Elasmopus levis alone; Gam: Gammarus mucronatus alone; 3 sp.: 3-species assemblage. Statistical analysis in Table 1

treatment $(p=0.0014 ;$ Fig. $3 a$, Table 1$)$, and the composition of the grazer community was dominated by Gammarus (Fig. 3b). However, grazer diversity did not decrease stochastic variation in grazer biomass or increase grazer community resistance to stressors (Table 2). Overall, grazer presence and species richness had strong and significant effects in this experiment.

Abiotic stressors also significantly influenced all primary producers. Elevated temperatures significantly decreased Zostera biomass ( $p=0.013$; Fig. 2a, Table 1), but significantly increased epiphytic algal biomass ( $p=0.0116$; Fig. $2 b$, Table 1). There was no effect of warming on grazers, macroalgae, or sessile invertebrates. Nutrient enrichment, which elevated nutrients to approximately 5 times ambient levels, had the strongest effect on Zostera and significantly reduced its biomass in all enriched treatments $(\mathrm{p}<$
0.0001; Fig. 2a, Table 1). Macroalgal biomass was also lower in the nutrient enriched treatments $(p=$ 0.0087; Fig. 2c, Table 1). Conversely, epiphytic algal biomass was greater in the presence of nutrient enrichment ( $p=0.0011$; Fig. $2 b$, Table 1). Thus, both nutrient enrichment and warming increased microalgae but decreased macrophytes. Epiphytic algal biomass was generally lower and more stable in the face of stressors in treatments with multiple grazer species relative to the average of treatments with a single grazer species ( $p=0.04519$; Fig. $2 b$, Table 2$)$. This was not the case for macroalgal or Zostera biomass, which showed no difference in either stochastic or resistance stability with grazer species richness (Table 2). In this experiment, warming and nutrient enrichment had similarly strong effects on primary producers, but the direction of the effect differed among producers. 

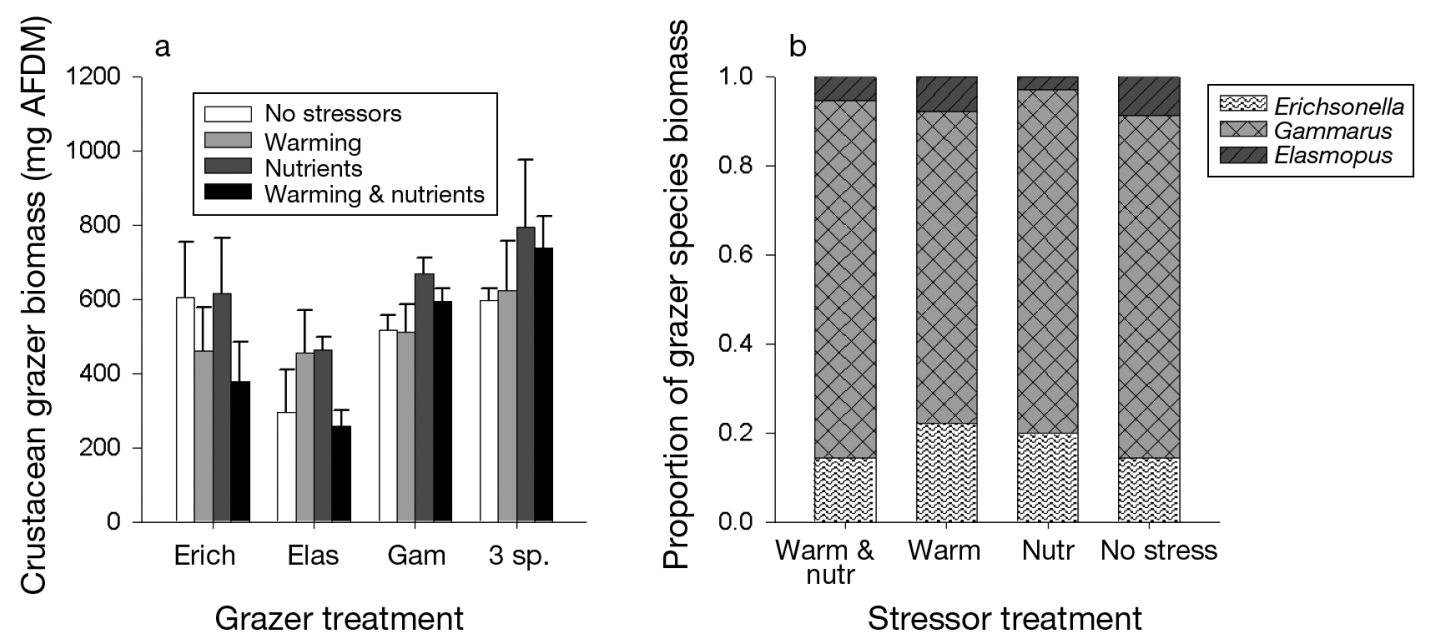

Fig. 3. (a) Final crustacean grazer biomass $( \pm 1 \mathrm{SE})$ for all experimental treatments. Grazer treatment abbreviations as in Fig. 2. Statistical analysis is in Table 1. (b) Final proportion of crustacean grazer species biomass (g AFDM) in the 3-species assemblage treatments. Warm \& nutr: warming and nutrient enrichment; Warm: warming; Nutr: nutrient enrichment; No stress: no stressors

Table 2. Results of 2-sample Welch t-tests examining the effects of species richness on stochastic (within treatment) and resistance (among treatment) stability. Tests were performed on deviations from the median (BrownForsythe test), and were conducted using R. Values significant at 0.05 are in bold. Ab. dev.: absolute deviation; Rel. dev.: relative deviation

\begin{tabular}{|c|c|c|c|c|}
\hline \multirow[t]{2}{*}{ Response } & \multicolumn{2}{|c|}{ Stochastic stability } & \multicolumn{2}{|c|}{ Resistance stability } \\
\hline & Ab. dev. & Rel. dev. & Ab. dev. & Rel. dev. \\
\hline Grazer biomass & 0.3432 & 0.2964 & 0.9528 & 0.4565 \\
\hline Zostera shoot biomass & 0.1394 & 0.7743 & 0.1062 & 0.0736 \\
\hline $\begin{array}{l}\text { Epiphytic algal biomass } \\
(\log \text { chl a) }\end{array}$ & 0.1862 & 0.4333 & 0.06579 & 0.04519 \\
\hline Macroalgal biomass & 0.9529 & 0.6675 & 0.8005 & 0.5598 \\
\hline Sessile invertebrate biomas & ss 0.0854 & 0.6297 & 0.4483 & 0.9227 \\
\hline
\end{tabular}

algae than other treatments (Fig. 4a). Erichsonella-only treatments were intermediate, and contained approximately equal amounts of red and green algae, and moderate biomass of sessile invertebrates (Fig. $4 \mathrm{a}, \mathrm{c}$ ). However, variation among these communities was minimal, with similar variance within all grazer treatments ( $p=0.50$, betadisper test).

Communities were also structured by nutrient enrichment $(\mathrm{p}=0.001$; Fig. $4 \mathrm{~b}$, Table 3), which reduced biomass of Zostera (see Fig. 4a,b). But variation among nutrient-enriched communities was less than variation

\section{Community structure}

NMDS analysis showed that experimental communities were significantly structured by all 3 treatments (grazer species, warming, nutrient enrichment). Crustacean grazer species treatments structured the experimental communities not only by their presence, but also by their identity ( $p=0.0009$; Fig. $4 \mathrm{c}$, Table 3 ). Species-rich and Gammarus-only treatments were similar (Fig. 4c), reflecting the dominance of this species in multi-species grazer assemblages, and contained more red algae (Ceramium spp. and Polysiphonia spp.) but less green algae (Enteromorpha spp. and Cladophora spp.) than other treatments (Fig. 4a). Alternatively, no-grazer and Elasmopus-only treatments were similar (Fig. 4c), and contained more green algae and sessile invertebrates but less red among non-enriched communities, meaning nutrient enrichment made communities more similar $(\mathrm{p}=$ 0.028 , betadisper test). Warming also significantly influenced experimental community structure $(\mathrm{p}=$ 0.004; Fig. 4d, Table 3), but to a slightly lesser degree than nutrients or grazers, and did not change community similarity $(p=0.61$, betadisper test). Warmed communities generally had lower Zostera biomass, a pattern similar to nutrient-enriched communities.

\section{Stressors and species identity}

The SEM model (Fig. 5a), used to explore complex interactions at the species level, showed that final grazer species abundances were influenced by both initial grazer assemblage composition and by stres- 

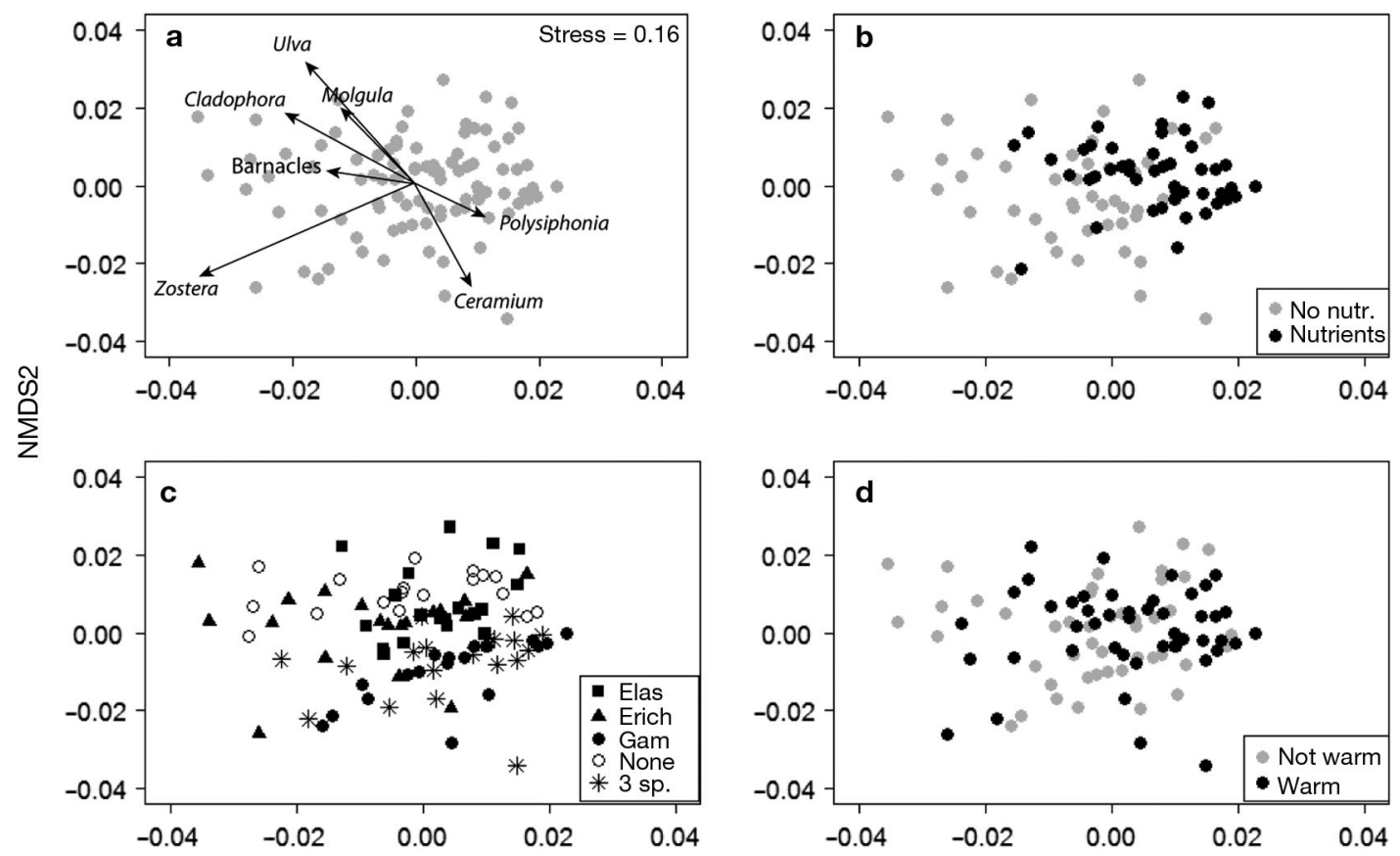

NMDS1

Fig. 4. Non-metric multi-dimensional scaling (NMDS) ordination of all invertebrate and algal species (stress =0.16); each point represents the community in a single mesocosm. (a) Plot of all mesocosm communities (points), and species with the most influence (vectors), (b) same plot as (a) color-coded by nutrient addition treatment (c) same plot as (a) with shapes representing the crustacean grazer treatments (see Fig. 2 for abbreviations) (d) same plot as (a) color-coded by warming treatment

Table 3. Results from PERMANOVA analysis, testing for differences in community structure with experimental treatment. This analysis used square-root transformed data and a Bray-Curtis dissimilarity matrix, as used for the NMDS ordination in Fig. 4

\begin{tabular}{|lccccc|}
\hline Factor & df & SS & MS & $F$ & $p$ \\
\hline Grazer species (Sp.) & 4 & 0.0034 & 0.0008 & 8.5577 & $\mathbf{0 . 0 0 1}$ \\
Warming (Warm.) & 1 & 0.0004 & 0.0004 & 4.5097 & $\mathbf{0 . 0 0 4}$ \\
Nutrients (Nuts.) & 1 & 0.0018 & 0.0018 & 18.0309 & $\mathbf{0 . 0 0 1}$ \\
Sp. $\times$ Warm. & 4 & 0.0003 & 0.0001 & 0.8806 & 0.604 \\
Sp. $\times$ Nuts. & 4 & 0.0003 & 0.0001 & 0.8722 & 0.588 \\
Warm. $\times$ Nuts. & 1 & 0.0000 & 0.0000 & 0.1726 & 0.904 \\
Sp. $\times$ Warm. $\times$ Nuts. & 4 & 0.0002 & 0.0001 & 0.5363 & 0.901 \\
Error & 76 & 0.0075 & 0.0001 & & \\
\hline
\end{tabular}

sors. Presence of both Elasmopus and Gammarus reduced Erichsonella abundance in 3-species treatments, and together with the negative impacts of warming, explained $70 \%$ of the variation in Erichsonella abundance (Fig. 5b, Table 4). Our model also suggests that Gammarus and Elasmopus had direct positive effects on each other and explained about $70 \%$ of the variation in abundance of each species (Fig. 5b, Table 4), but this is likely an artifact of the experimental design (see 'Discussion'). Gammarus was the only grazer species whose final abundance had a direct, negative impact on primary producers, specifically macroalgal biomass. As shown in the analysis of community structure, warming and nutrient enrichment increased epiphytic algal biomass $\left(\mathrm{R}^{2}=0.21\right.$; Fig. 5b), while nutrients reduced Zostera and macroalgal biomass $\left(\mathrm{R}^{2}=0.29\right.$ and $\mathrm{R}^{2}=0.21$ respectively; Fig. 5b).

\section{DISCUSSION}

The effects of multiple stressors are frequently assumed to be additive (Crain et al. 2008). However, changes in biodiversity occurring simultaneously with multiple stressors may have additive or synergistic effects, because diversity is important in providing temporal, resistance, and resilience stability in ecosystems (Tilman 1996, 1999, Griffin et al. 2009). Less diverse communities have fewer ecological redundancies, leading to less stable ecosystem properties in the face of stressors (Breitburg et al. 1998, Hooper et al. 2005). Our results demonstrate additive effects among diversity change, 

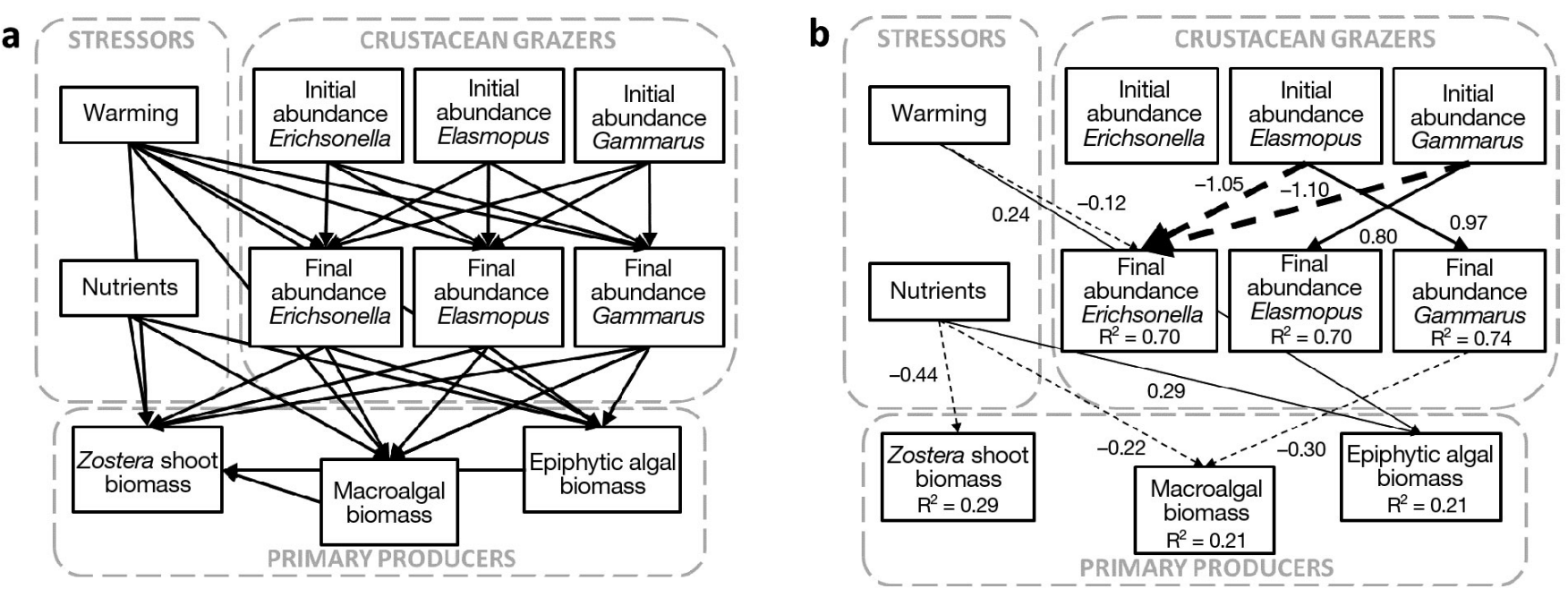

Fig. 5. (a) Full structural equation model (SEM) that was estimated for this experiment, with warming and nutrients as stressors. (b) Graphical results from analysis of model shown in (a). Only paths significant at $\mathrm{p}=0.05$ are shown; all path coefficients are standardized. Solid and dashed lines represent positive and negative relationships respectively; line thickness indicates the explanatory power of a path. Results in Table 4

Table 4. Results from SEM examining the experimental effects of warming, nutrients, and grazer species richness (see Fig. 5). Each line indicates one path in the model, with the arrow showing the direction of the effect. Significant path coefficients ( $p=$ 0.05 ) are in bold. Whole-model chi-square $=22.404, \mathrm{df}=21, \mathrm{p}=0.377$. Stand. est.: standardized estimate; unstand. est.: unstandardized estimate; CR: critical ratio

\begin{tabular}{|c|c|c|c|c|c|c|c|}
\hline Model path & & & Stand. est. & Unstand. est. & SE & $\mathrm{CR}$ & $\mathrm{p}$ \\
\hline Final Elasmopus abundance & $\leftarrow$ & Warming & -0.022 & -24.45 & 71.07 & -0.344 & 0.731 \\
\hline Final Gammarus abundance & $\leftarrow$ & Warming & -0.032 & -36.191 & 66.047 & -0.548 & 0.584 \\
\hline Final Erichsonella abundance & $\leftarrow$ & Warming & -0.124 & -27.007 & 13.764 & -1.962 & 0.05 \\
\hline Final Elasmopus abundance & $\leftarrow$ & Initial Erichsonella abundance & -0.043 & -4.008 & 21.306 & -0.188 & 0.851 \\
\hline Final Gammarus abundance & $\leftarrow$ & Initial Erichsonella abundance & 0.116 & 10.796 & 19.8 & 0.545 & 0.586 \\
\hline Final Erichsonella abundance & $\leftarrow$ & Initial Erichsonella abundance & -0.256 & -4.63 & 3.536 & -1.309 & 0.19 \\
\hline Final Elasmopus abundance & $\leftarrow$ & Initial Gammarus abundance & 0.797 & 73.965 & 21.282 & 3.476 & $<0.0001$ \\
\hline Final Gammarus abundance & $\leftarrow$ & Initial Gammarus abundance & 0.11 & 10.101 & 19.777 & 0.511 & 0.61 \\
\hline Final Erichsonella abundance & $\leftarrow$ & Initial Gammarus abundance & -1.096 & -19.526 & 3.617 & -5.399 & $<0.0001$ \\
\hline Final Elasmopus abundance & $\leftarrow$ & Initial Elasmopus abundance & -0.039 & -3.607 & 21.259 & -0.17 & 0.865 \\
\hline Final Gammarus abundance & $\leftarrow$ & Initial Elasmopus abundance & 0.969 & 87.523 & 19.757 & 4.43 & $<0.0001$ \\
\hline Final Erichsonella abundance & $\leftarrow$ & Initial Elasmopus abundance & -1.053 & -18.527 & 3.615 & -5.125 & $<0.0001$ \\
\hline Epiphytic algal biomass & $\leftarrow$ & Final Elasmopus abundance & -0.231 & 0 & 0 & -1.596 & 0.111 \\
\hline Macroalgal biomass & $\leftarrow$ & Final Elasmopus abundance & 0.147 & 0 & 0 & 1.02 & 0.308 \\
\hline Epiphytic algal biomass & $\leftarrow$ & Final Gammarus abundance & 0.067 & 0 & 0 & 0.47 & 0.638 \\
\hline Macroalgal biomass & $\leftarrow$ & Final Gammarus abundance & -0.304 & 0 & 0 & -2.148 & 0.032 \\
\hline Epiphytic algal biomass & $\leftarrow$ & Final Erichsonella abundance & -0.059 & 0 & 0 & -0.43 & 0.668 \\
\hline Macroalgal biomass & $\leftarrow$ & Final Erichsonella abundance & 0.056 & 0 & 0 & 0.407 & 0.684 \\
\hline Epiphytic algal biomass & $\leftarrow$ & Nutrients & 0.287 & 0.012 & 0.004 & 2.812 & 0.005 \\
\hline Macroalgal biomass & $\leftarrow$ & Nutrients & -0.223 & -0.014 & 0.006 & -2.186 & 0.029 \\
\hline Epiphytic algal biomass & $\leftarrow$ & Warming & 0.237 & 0.076 & 0.033 & 2.274 & 0.023 \\
\hline Macroalgal biomass & $\leftarrow$ & Warming & -0.016 & -0.007 & 0.048 & -0.152 & 0.879 \\
\hline Zostera biomass & $\leftarrow$ & Final Elasmopus abundance & -0.217 & 0 & 0 & -1.48 & 0.139 \\
\hline Zostera biomass & $\leftarrow$ & Final Gammarus abundance & -0.128 & 0 & 0 & -0.885 & 0.376 \\
\hline Zostera biomass & $\leftarrow$ & Final Erichsonella abundance & 0.177 & 0.001 & 0.001 & 0.993 & 0.321 \\
\hline Zostera biomass & $\leftarrow$ & Macroalgal biomass & -0.041 & -0.082 & 0.188 & -0.438 & 0.662 \\
\hline Zostera biomass & $\leftarrow$ & Epiphytic algal biomass & -0.155 & -0.447 & 0.269 & -1.661 & 0.097 \\
\hline Zostera biomass & $\leftarrow$ & Nutrients & -0.439 & -0.054 & 0.011 & -4.912 & $<0.0001$ \\
\hline Zostera biomass & $\leftarrow$ & Warming & -0.112 & -0.104 & 0.095 & -1.088 & 0.277 \\
\hline
\end{tabular}


warming, and nutrient enrichment stressors in this mesocosm experiment because we did not observe any interactions. The absence of non-additive interactions among environmental stressors and changes in diversity may indicate that these factors act independently in this system. However, we did observe increased resistance stability of epiphytic algae in the face of stressors in higher diversity grazer assemblages, demonstrating that diversity can buffer certain ecosystem processes against stressor impacts. If the additive effects we observed are general, ecological consequences of these stressors will still need to be evaluated for each ecosystem process of interest, but interpretation and prediction of ecosystem changes may be more straightforward.

Grazer presence and changing species richness had larger overall effects than warming or nutrient enrichment on all response variables except Zostera biomass in these experimental mesocosm communities (Table 1), in which we attempted to use realistic levels of variation in each stressor. Biomass of grazers in the mesocosms, standardized to biomass of seagrass, was comparable (within $1 \mathrm{SD}$ ) to the biomass of grazers in local field collections (Douglass et al. 2010). As found previously, grazers reduced biomass not only of epiphytic microalgae and macroalgae, but also of sessile invertebrates (Fig. 2, Table 1) (Bell 1991, Duffy \& Hay 2000, Duffy \& Harvilicz 2001, Moksnes et al. 2008). This reduction in sessile invertebrate biomass with grazing is likely due to nonconsumptive removal of newly-settled barnacles and tunicates from the Zostera blades and tank surfaces by grazing amphipods and isopods (Osman \& Whitlatch 1995, 2004).

Reductions in epiphytes via grazing are often assumed to lead to increases in Zostera biomass due to alleviation of light limitation. We did not observe this, likely because light levels in the mesocosms were high enough, despite shading screens, to effectively eliminate the competitive impacts of epiphytes. In addition, the length of this experiment (6 wk) may not have been long enough to observe strong competitive effects of epiphytes on Zostera. However, recent field experiments in this same system show that when grazers are removed, epiphytic algal overgrowth can greatly reduce Zostera biomass (Whalen et al. in press). Reductions in epiphytes via grazing are likely important for seagrasses over longer time frames than this experiment encompassed, and under lower light conditions when competition may play a greater role.

We found that more diverse grazer assemblages produced higher grazer biomass, as suggested by ecological theory (Carlander 1955, Mulder et al. 2001, Gamfeldt \& Hillebrand 2008) and demonstrated by prior research in this system (Duffy et al. 2003). Perhaps this is because the experimental stressors did not impact grazer biomass directly (Table 1 ), or interact with species richness mechanisms (facilitation, niche complementarity, sampling effect) (Mulder et al. 2001).

Species-rich grazer assemblages also potentially provide resistance stability by maintaining ecosystem processes and properties in the face of stressors. We found that increasing grazer species richness buffered epiphytic algae against stressor impacts by increasing the resistance stability of epiphytic algal biomass (Fig. 2, Table 2) (Griffin et al. 2009), as shown previously with warming and salinity stressors in this system (Blake \& Duffy 2010). We saw this stabilizing effect of grazer species richness despite strong stressor effects on primary producers. This may be because interaction strengths between grazers and epiphytic algae remain high in the 3-grazerspecies communities due to the dominance of the strong consumer Gammarus (Zimmerman et al. 1979, Duffy \& Harvilicz 2001, Thébault \& Loreau 2005, Douglass et al. 2010). In the future, it will be important to test diverse grazer assemblages of differing compositions in order to isolate diversity and composition effects and determine the generality of these results.

Finally, grazer identity and composition structured the mesocosm communities through differing preferential consumption of macroalgal species (Fig. $4 \mathrm{a}, \mathrm{c}$ ). Green algae were consumed by all grazers, but red algae were not consumed by Gammarus (Duffy \& Harvilicz 2001). Overall, the dominant effect of grazer presence and species richness confirm that grazing is an important ecosystem process, and that changes in mesograzer species composition and diversity can have impacts on primary producers and epifaunal and epiphytic community composition comparable to or greater than those of environmental stressors.

Warming and nutrient enrichment had larger effects on Zostera biomass than variation in grazer assemblages (Fig. 2, Table 1). The experimental addition of nutrients to the water column reduced Zostera biomass by $22 \%$ on average (Table 1 ), as shown in many previous studies (see review by Hughes et al. 2004). This direct, negative, physiological effect of nutrients is likely due to increased nitrogen uptake and resulting carbon limitation (Touchette \& Burkholder 2000), but may have co-occurred with shading from epiphytic algal over-growth in no-grazer treatments, 
exacerbating the negative effects of nutrient addition. Nutrient additions also had a smaller but significantly negative effect on macroalgal biomass (Figs. $2 \& 5$, Tables $1 \& 4$ ). This may be because grazers consumed almost all standing algal biomass, primarily palatable green algae, in nutrient addition treatments (Burkepile \& Hay 2006).

Warming treatments, which increased temperatures approximately 2 to $3^{\circ} \mathrm{C}$ and doubled the number of days with temperatures above $30^{\circ} \mathrm{C}$ (Fig. 1), significantly increased epiphytic algal biomass but reduced Zostera biomass (Table 1). This $30^{\circ} \mathrm{C}$ threshold appears to be near the physiological limit of Zostera, and likely increases the compensating light requirements above available light levels in Chesapeake Bay (Moore et al. 1997), leading to summer-time Zostera die-offs (Moore \& Jarvis 2008). Overall, stressors produced conditions favoring higher standing biomass of 'nuisance' microalgae at the expense of macroalgae or eelgrass. If this holds true at an ecosystem scale, the impacts of climate warming in eutrophied systems such as Chesapeake Bay may be especially large.

SEM corroborated many results from the other analyses, but also provided additional insights into the structure of, and effects within, these experimental communities. In this analysis, we modeled grazer species individually in order to examine stressor effects on each species. However, modeling grazer species this way made detection of grazer presence and richness effects unlikely. The positive effects of warming and nutrient enrichment on epiphytic algae, and the negative effects on Zostera and macroalgae seen in ANOVA results were again evident. The isopod Erichsonella was significantly less abundant under warmed conditions, which follows a trend of reduced biomass in the warmest month (August) in York River, Virginia, field collections over several years (Douglass et al. 2010). The presence of other grazer species also appeared to reduce the abundance of Erichsonella, likely because Erichsonella is a poor competitor, especially when grazer populations have had sufficient time to near carrying capacity in the mesocosms and competition for algal food resources is at a maximum. The apparent positive effects of the other 2 grazer species, Elasmopus and Gammarus, on each other in this SEM are likely an artifact of the substitutive design of this experiment: since initial numbers of all species were lowest in the 3-species treatments, similar final densities of species across treatments would appear as higher population growth rates in the 3-species treatment. Finally, Gammarus had a strong negative effect on macroalgal biomass through consumption. This is also evident in Fig. 2, but not in the ANOVA results (Table 1) because grazer species were analyzed together. This consumptive effect is significant despite Gammarus' documented promotion of red algae, which can lead to overall higher macroalgal biomass (Duffy \& Harvilicz 2001). However, Gammarus remains a strong consumer of most other macro- and microalgae (Zimmerman et al. 1979). Thus, SEM provides information complementary to the ANOVA results that helps tease apart the effects of individual species and interactions among factors.

The present study shows that grazer presence and diversity can have comparable or larger effects on community structure than warming and nutrient enrichment stressors in an experimental temperate seagrass system. Diversity is important for maintaining critical ecosystem processes, such as grazing, in the face of multiple stressors (Elmqvist et al. 2003, Larsen et al. 2005, Valentine \& Duffy 2006, Blake \& Duffy 2010), and grazing in seagrass systems has effects similar in magnitude to water column nutrient enrichment (Neckles et al. 1993, Hughes et al. 2004). However, we see that nutrients and warming favor ephemeral and epiphytic algae over eelgrass, potentially leading to a shift in basal primary producer composition as coastal nutrient enrichment remains unabated and the climate continues to warm. These results might suggest a bleak future for temperate estuarine seagrass systems, but also emphasize that these processes depend strongly on stressor identity and the composition of the grazer assemblage. Experimental grazer richness manipulations such as ours are often logistically constrained and cannot capture the range of species richness in the field, and experimental manipulations of warming and nutrient additions can only simulate actual conditions for a short duration. However, recent experiments suggest that grazer control of epiphytic algae is similarly important in field settings (Cook et al. 2011, Whalen et al. in press). Whether these patterns of diversity and stressor effects hold true for other larger experimental and natural systems remains a topic for further investigation. This work highlights the importance of evaluating the impacts of climate warming on individual species as well as the entire system, and reexamining the effects of potential interactions between environmental stressors and the structure of consumer assemblages as climate change continues.

Acknowledgements. Special thanks to C. Smoot, J. P. Richardson, M. Whalen, K. Sobocinski, S. Blake, A. Popowich, S. Bornbush, H. Richardson, M. Blake, E. Blake, J. Douglass, A. Spivak, P. Reynolds, and Q. Roberts for their 
assistance, advice, and support. This project was funded by NSF OCE-0623874. This is contribution no. 3243 of the Virginia Institute of Marine Science, College of William and Mary.

\section{LITERATURE CITED}

Allison G (2004) The influence of species diversity and stress intensity on community resistance and resilience. Ecol Monogr 74:117-134

Arbuckle JL (2011) Amos. AMOS Development Corporation, Crawfordsville, FL

Balvanera P, Pfisterer AB, Buchmann N, He J, Nakashizuka T, Raffaelli D, Schmid B (2006) Quantifying the evidence for biodiversity effects on ecosystem functioning and services. Ecol Lett 9:1146-1156

Bell SS (1991) Amphipods as insect equivalents? Ecology 72: 350-354

> Bintz JC, Nixon SW, Buckley BA, Granger SL (2003) Impacts of temperature and nutrients on coastal lagoon plant communities. Estuaries 26:765-776

Blake R, Duffy JE (2010) Grazer diversity affects resistance to multiple stressors in an experimental seagrass ecosystem. Oikos 119:1625-1635

Breitburg DL, Baxter JW, Hatfield CA, Howarth RW, Jones CG, Lovett GM, Wigand C (1998) Understanding effects of multiple stressors: ideas and challenges. In: Pace ML, Groffman PM (eds) Successes, limitations, and frontiers in ecosystem science. Springer-Verlag, New York, NY, p 416-431

> Brown MB, Forsythe $\mathrm{AB}$ (1974) Robust tests for the equality of variances. J Am Stat Assoc 69:364-367

Burkepile DE, Hay ME (2006) Herbivore vs. nutrient control of marine primary producers: context-dependent effects. Ecology 87:3128-3139

Burkholder JM, Tomasko DA, Touchette BW (2007) Seagrasses and eutrophication. J Exp Mar Biol Ecol 350: 46-72

Caldeira MC, Hector A, Loreau M, Pereira JS (2005) Species richness, temporal variability and resistance of biomass production in a Mediterranean grassland. Oikos 110: 115-123

Canuel EA, Spivak AC, Waterson EJ, Duffy JE (2007) Biodiversity and food web structure influence short-term accumulation of sediment organic matter in an experimental seagrass system. Limnol Oceanogr 52:590-602

> Cardinale BJ, Duffy JE, Gonzalez A, Hooper DU and others (2012) Biodiversity loss and its impact on humanity. Nature 486:59-67

> Carlander KD (1955) The standing crop of fish in lakes. J Fish Res Board Can 12:543-570

> Cook K, Vanderklift MA, Poore AGB (2011) Strong effects of herbivorous amphipods on epiphyte biomass in a temperate seagrass meadow. Mar Ecol Prog Ser 442:263-269

> Crain CM, Kroeker K, Halpern BS (2008) Interactive and cumulative effects of multiple human stressors in marine systems. Ecol Lett 11:1304-1315

Cruz-Rivera E, Hay ME (2000) Can quantity replace quality? Food choice, compensatory feeding, and fitness of marine mesograzers. Ecology 81:201-219

Doney SC, Ruckelshaus M, Duffy JE, Barry JP and others (2012) Climate change impacts on marine ecosystems. Ann Rev Mar Sci 4:11-37

> Douglass J, France KE, Richardson JP, Duffy JE (2010) Sea- sonal and interannual change in a Chesapeake Bay eelgrass community: insights into biotic and abiotic control of community structure. Limnol Oceanogr 55:1499-1520

> Duarte CM (2000) Marine biodiversity and ecosystem services: an elusive link. J Exp Mar Biol Ecol 250:117-131

Duarte CM, Middelburg JJ, Caraco N (2005) Major role of marine vegetation on the oceanic carbon cycle. Biogeosciences 2:1-8

> Duffy JE, Harvilicz AM (2001) Species-specific impacts of grazing amphipods in an eelgrass-bed community. Mar Ecol Prog Ser 223:201-211

Duffy JE, Hay ME (2000) Strong impacts of grazing amphipods on the organization of a benthic community. Ecol Monogr 70:237-263

> Duffy JE, Richardson JP, Canuel EA (2003) Grazer diversity effects on ecosystem functioning in seagrass beds. Ecol Lett 6:637-645

> Edgar GJ (1990) The use of the size structure of benthic macrofaunal communities to estimate faunal biomass and secondary production. J Exp Mar Biol Ecol 137: 195-214

- Elmqvist T, Folke C, Nyström M, Peterson G, Bengtsson J, Walker B, Norberg J (2003) Response diversity, ecosystem change, and resilience. Front Ecol Environ 1: 488-494

Gamfeldt L, Hillebrand H (2008) Biodiversity effects in aquatic ecosystem functioning-maturation of a new paradigm. Int Rev Hydrobiol 93:550-564

Grace JB (2006) Structural equation modeling and natural systems. Cambridge University Press, Cambridge

> Grace JB, Anderson TM, Olff H, Scheiner SM (2010) On the specification of structural equation models for ecological systems. Ecol Monogr 80:67-87

Griffin JN, O'Gorman EJ, Emmerson MC, Jenkins SR, Klein A, Loreau M, Symstad A (2009) Biodiversity and the stability of ecosystem functioning. In: Naeem S, Bunker DE, Hector A, Loreau M, Perrings C (eds) Biodiversity, ecosystem functioning, and human wellbeing. Oxford University Press, New York, NY, p 78-93

Griffiths BS, Ritz K, Bardgett RD, Cook R and others (2000) Ecosystem response to pasture soil communities to fumigation-induced microbial diversity reductions: an examination of the biodiversity-ecosystem function relationship. Oikos 90:279-294

Hauxwell J, Cebrian J, Furlong C, Valiela I (2001) Macroalgal canopies contribute to eelgrass (Zostera marina) decline in temperate estuarine ecosystems. Ecology 82: 1007-1022

Hays CG (2005) Effect of nutrient availability, grazer assemblage and seagrass source population on the interaction between Thalassia testudinum (turtle grass) and its algal epiphytes. J Exp Mar Biol Ecol 314:53-68

> Heck KL, Hays G, Orth RJ (2003) Critical evaluation of the nursery role hypothesis for seagrass meadows. Mar Ecol Prog Ser 253:123-136

> Hoegh-Guldberg O, Bruno JF (2010) The impact of climate change on the world's marine ecosystems. Science 328: 1523-1528

Hooper DU, Chapin FS, Ewel JJ, Hector A and others (2005) Effects of biodiversity on ecosystem functioning: a consensus of current knowledge. Ecol Monogr 75:3-35

Hooper DU, Adair EC, Cardinale BJ, Byrnes JE and others (2012) A global synthesis reveals biodiversity loss as a major driver of ecosystem change. Nature 486:105-108

Hughes AR, Bando KJ, Rodriguez LF, Williams SL (2004) 
Relative effects of grazers and nutrients in seagrasses: a meta-analysis approach. Mar Ecol Prog Ser 282:87-99

> Jaschinski S, Sommer U (2011) How do nutrient conditions and species identity influence the impact of mesograzers in eelgrass-epiphyte systems? Mar Biol 158:193-203

Kemp WM, Boynton WR, Adolf JE, Boesch DF and others (2005) Eutrophication of Chesapeake Bay: historical trends and ecological interactions. Mar Ecol Prog Ser 303:1-29

> Larsen TH, Williams NM, Kremen C (2005) Extinction order and altered community structure rapidly disrupt ecosystem functioning. Ecol Lett 8:538-547

Levene H (1960). Robust tests for equality of variances. In: Olkin I (ed) Contributions to probability and statistics: essays in honor of Harold Hotelling. Stanford University Press, Stanford, CA, p 278-292

McArdle BH, Anderson MJ (2001) Fitting multivariate models to community data: a comment on distance-based redundancy analysis. Ecology 82:290-297

> McGranahan G, Balk D, Anderson B (2007) The rising tide: assessing the risks of climate change and human settlements in low elevation coastal zones. Environ Urban 19: $17-37$

Moksnes PO, Gullstrom M, Tryman K, Baden S (2008) Trophic cascades in a temperate seagrass community. Oikos 117:763-777

Moore KA, Jarvis JC (2008) Environmental factors affecting recent summertime eelgrass diebacks in the lower Chesapeake Bay: implications for long-term persistence. J Coast Res 55:135-147

> Moore KA, Wetzel RL (2000) Seasonal variations in eelgrass (Zostera marina L.) responses to nutrient enrichment and reduced light availability in experimental ecosystems. J Exp Mar Biol Ecol 244:1-28

> Moore KA, Wetzel RL, Orth RJ (1997) Seasonal pulses of turbidity and their relations to eelgrass (Zostera marina L.) survival in an estuary. J Exp Mar Biol Ecol 215:115-134

> Mulder CPH, Uliassi DD, Doak DF (2001) Physical stress and diversity-productivity relationships: the role of positive interactions. Proc Natl Acad Sci USA 98:6704-6708

- Najjar RG, Walker HA, Anderson PJ, Barron EJ and others (2000) The potential impacts of climate change on the mid-Atlantic coastal region. Clim Res 14:219-233

Najjar RG, Pyke CR, Adams MB, Breitburg DL and others (2010) Potential climate-change impacts on the Chesapeake Bay. Estuar Coast Shelf Sci 86:1-20

> Neckles HA, Wetzel RL, Orth RJ (1993) Relative effects of nutrient enrichment and grazing on epiphyte-macrophyte (Zostera marina L.) dynamics. Oecologia 93: 285-295

NOAA (2007) Warm summer in US ends with record heat in south, widespread drought continues in southeast, west. NOAA News Online (Story 2917). Available at www. noaanews.noaa.gov/stories2007/s2917.htm

Nyström M, Folke C, Moberg F (2000) Coral reef disturbance and resilience in a human-dominated environment. Trends Ecol Evol 15:413-417

Oksanen J, Blanchet FG, Kindt R, Legendre P and others (2011) vegan: community ecology package. R package version 1.17-11. Available at http://CRAN.R-project. org/package=vegan

Olejnik S, Algina J (2003) Generalized eta and omega squared statistics: measures of effect size for some common research designs. Psychol Methods 8:434-447

Orth RJ, Moore KA (1983) Chesapeake Bay: an unprece- dented decline in submerged aquatic vegetation. Science 222:51-53

Orth RJ, Moore KA (1988) Distribution of Zostera marina L. and Ruppia maritima L. sensu lato along depth gradients in the lower Chesapeake Bay, USA. Aquat Bot 32: 291-305

Orth RJ, Batiuk RA, Bergstrom PW, Moore KA (2002) A perspective on two decades of policies and regulations influencing the protection and restoration of submerged aquatic vegetation in Chesapeake Bay, USA. Bull Mar Sci 71:1391-1403

> Orth RJ, Carruthers TJB, Dennison WC, Duarte CM and others (2006) A global crisis for seagrass ecosystems. Bioscience 56:987-996

> Osman R, Whitlatch RB (1995) Predation on early ontogenetic life stages and its effect on recruitment into a marine epifaunal community. Mar Ecol Prog Ser 117: 111-126

> Osman R, Whitlatch RB (2004) The control of the development of a marine benthic community by predation on recruits. J Exp Mar Biol Ecol 311:117-145

> Oviatt CA (2004) The changing ecology of temperate coastal waters during a warming trend. Estuaries 27:895-904

Parsons TR, Maita Y, Lalli CM (1984) A manual of chemical and biological methods for seawater analysis. Pergamon Press, Oxford

Polte P, Schanz A, Asmus H (2005) The contribution of seagrass beds (Zostera noltii) to the function of tidal flats as a juvenile habitat for dominant, mobile epibenthos in the Wadden Sea. Mar Biol 147:813-822

R Development Core Team (2011) R: A language and environment for statistical computing. R Foundation for Statistical Computing, Vienna. Available at www.Rproject.org

Sainte-Marie B (1991) A review of the reproductive bionomics of aquatic gammaridean amphipods: variation of life history traits with latitude, depth, salinity, and superfamily. Hydrobiologia 223:189-227

Short FT, Neckles HA (1999) The effect of global climate change on seagrasses. Aquat Bot 63:169-196

Spivak AC, Canuel EA, Duffy JE, Richardson JP (2009) Nutrient enrichment and food web composition affect ecosystem metabolism in an experimental seagrass habitat. PLoS ONE 4:e7473

> Stachowicz JJ, Bruno JF, Duffy JE (2007) Understanding the effects of marine biodiversity on communities and ecosystems. Annu Rev Ecol Evol Syst 38:739-766

> Thébault E, Loreau M (2005) Trophic interactions and the relationship between species diversity and ecosystem stability. Am Nat 166:E95-E114

Tilman D (1996) Population versus ecosystem stability. Ecology 77:350-363

Tilman D (1999) The ecological consequences of changes in biodiversity: a search for general principles. Ecology 80: 1455-1474

> Tilman D, Lehman CL, Bristow CE (1998) Diversity-stability relationships: Statistical inevitability or ecological consequence? Am Nat 151:277-282

Touchette BW, Burkholder JM (2000) Review of nitrogen and phosphorus metabolism in seagrasses. J Exp Mar Biol Ecol 250:133-167

Touchette BW, Burkholder JM, Glasgow HB (2003) Variations in eelgrass (Zostera marina L.) morphology and internal nutrient composition as influenced by increased temperature and water column nitrate. Estuaries 26:142-155 
Valentine JF, Duffy JE (2006) The central role of grazing in seagrass ecology. In: Karkum AW, Orth RJ, Duarte CM (eds) Seagrasses: biology, ecology, and conservation. Springer, Dordrecht, p 463-501

VECOS (2012) Virginia estuarine and coastal observing system. Virginia Institute of Marine Science, Gloucester Point, VA. Available at http://www3.vims.edu/vecos/ Default.aspx

Vitousek PM, Aber JD, Howarth RW, Likens GE and others (1997) Human alteration of the global nitrogen cycle: sources and consequences. Ecol Appl 7:737-750

Editorial responsibility: Just Cebrian, Dauphin Island, Alabama, USA
Whalen MA, Duffy JE, Grace JB (in press) Temporal shifts in top-down versus bottom-up control of epiphytic algae in a seagrass ecosystem. Ecology, doi:10. 1890/12-0156.1

Worm B, Lotze HK, Bostrom C, Engkvist R, Labanauskas V, Sommer U (1999) Marine diversity shift linked to interactions among grazers, nutrients, and propagule banks. Mar Ecol Prog Ser 185:309-314

Zimmerman R, Gibson R, Harrington J (1979) Herbivory and detritivory among gammaridean amphipods from a Florida seagrass community. Mar Biol 54:41-47

Submitted: March 21, 2012; Accepted: August 13, 2012

Proofs received from author(s): November 20, 2012 